\title{
Lesser-trélat sign in a patient with neoplasia of upper eyelid
}

\section{Satyaki Ganguly, Kranti C Jaykar, Sambeet Kumar Mallik}

\section{CASE REPORT}

A 40-year-old female presented to the dermatology OPD with an ulcerating growth of the left upper eyelid for the last three years. The growth was gradually increasing in size. On examination, there was an irregular erythematous swelling involving the whole of left upper eyelid with ulceration and areas of necrosis in the lateral part. A provisional diagnosis of sebaceous gland carcinoma was made. A biopsy of the eyelid growth was advised to confirm the diagnosis. Along with eyelid lesion, numerous asymptomatic, darkly pigmented papules were discovered over the face, trunk and extremities. These were more over the flexures like the neck, axilla, sub-mammary area and groin (Figures 1, 2). On being questioned about the lesions, the patient said that these lesions have appeared rapidly over a period of last six months. Detailed haematological, biochemical investigations, chest X-ray, upper gastrointestinal endoscopy, lower gastrointestinal endoscopy, mammography, abdominal ultrasound and bone marrow examination failed to reveal evidence of any systemic malignancy. Based on the clinical findings, a diagnosis of Lesser-Trélat sign in association with skin malignancy was made. The patient was referred to

\footnotetext{
Satyaki Ganguly ${ }^{1}$, Kranti C Jaykar ${ }^{2}$, Sambeet Kumar Mallik ${ }^{3}$

Affiliations: ${ }^{1}$ Assistant Professor, Dept of Dermatology, Venereology and Leprosy Pondicherry Institute of Medical sciences, Pondicherry; ${ }^{2}$ Assistant Professor, Dept of Dermatology, Venereology and Leprosy Katihar Medical College, Katihar, Bihar; 3Junior resident, Dept of Dermatology, Venereology and Leprosy Katihar Medical College, Katihar, Bihar.

Corresponding Author: Dr. Satyaki Ganguly, Dept of Dermatology, Venereology and Leprosy Pondicherry Institute of Medical sciences, Pondicherry-605014; Email: satyakiganguly@yahoo.co.in
}

Received: 19 November 2011

Accepted: 13 April 2012

Published: 01 January 2013

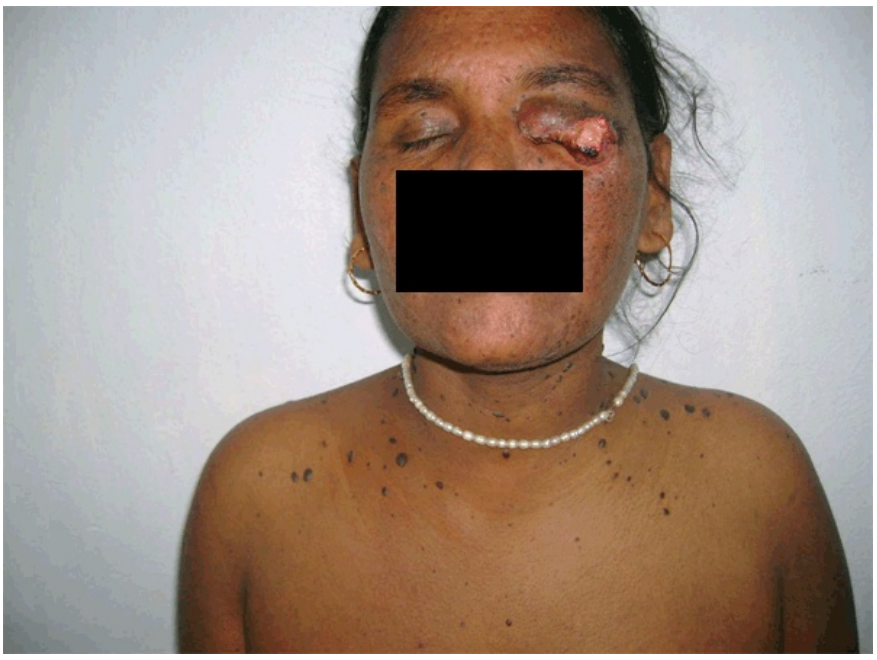

Figure 1: Lesser-Trélat sign: Upper eyelid tumour with numerous seborrheic keratoses over face and neck.

ophthalmology department for further management of the growth in the eyelid. Unfortunately, before a biopsy could be done the patient was lost to follow-up.

\section{DISCUSSION}

Seborrhoeic keratosis is a benign tumor, frequently pigmented, more common in elderly and composed of epidermal keratinocytes. The sudden appearance of numerous seborrhoeic keratoses in an adult may be a cutaneous finding of internal malignancy. Internal malignancy associated with the sudden development of numerous seborrhoeic keratoses in an eruptive fashion, with or without pruritus, is known as the sign of Lesser-Trélat [1]. Weakened subepithelial matrix-from the effects of neoplasm on the extracellular matrix of the host-has been postulated as a possible cause of Lesser -Trélat sign. To be considered a case of Lesser-Trélat, the keratoses should begin at approximately the same time as the development of cancer and run a parallel course in regard to growth and remission. 


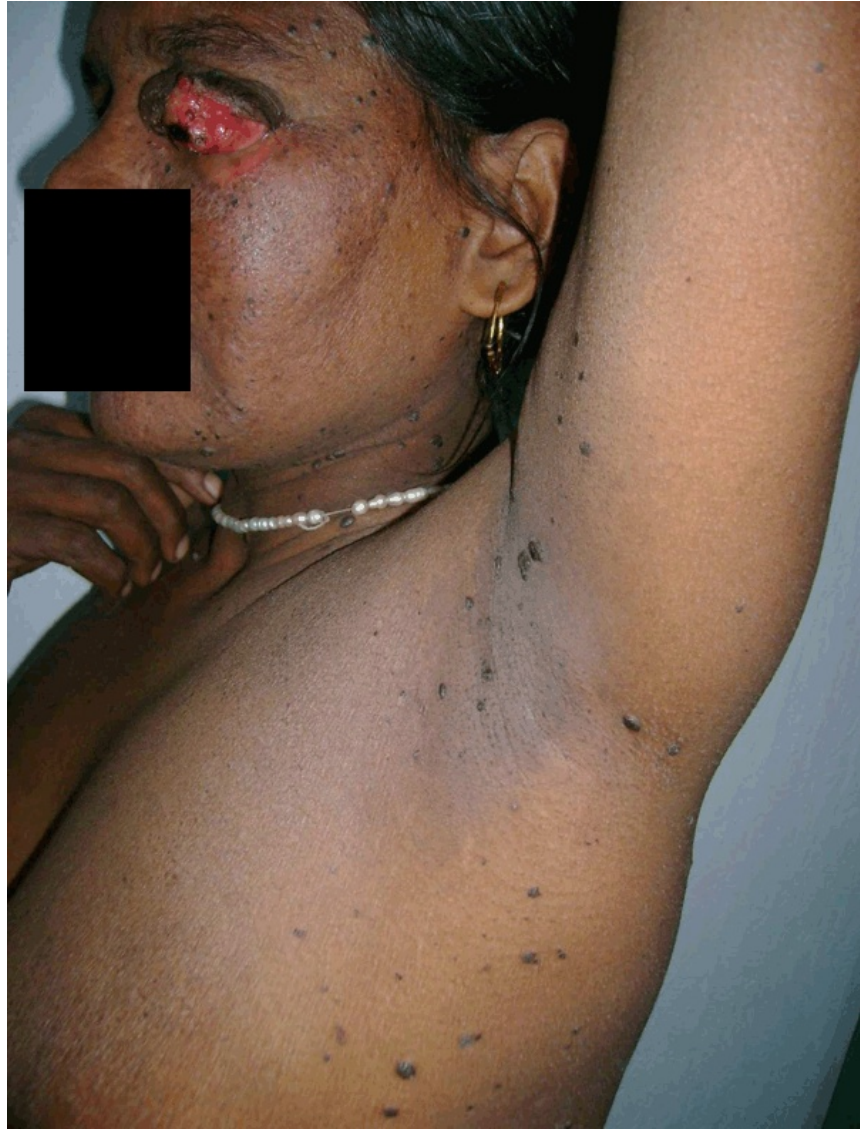

Figure 2: Lesser-Trélat sign: Upper eyelid tumor with numerous seborrheic keratoses over axilla.

Common malignancies associated with this sign are adenocarcinoma of stomach (most common), lung, colon, breast, prostate, lymphoma, leukemia, ovarian cancer, nasopharyngeal carcinoma and transitional cell carcinoma of the bladder [2]. It has been associated with skin malignancies like maligna melanoma [3], lymphocytoma cutis [4] Paget's disease [5], and Sezary syndrome [6]. A sudden eruption of many seborrhoeic keratoses may follow exfoliative erythroderma, erthrodermic psoriasis, erythrodermic drug eruption, lepromatous leprosy and HIV infection [7]. Sebaceous gland carcinomas are very rare tumors, usually arises from the meibomian glands and majority of lesions affect the upper eye lid. The lesions are nodular and appear like a chalazion which lasts for more than six months.

\section{CONCLUSION}

Internal malignancy associated with the sudden development of numerous seborrhoeic keratoses in an eruptive fashion, with or without pruritus, is known as the sign of Lesser-Trélat
Ganguly S, Jaykar KC, Mallik SK. Lesser-trélat sign in a patient with neoplasia of upper eye lid. International Journal of Case Reports and Images; 4(1):83-85.

$* * * * * * * * *$

doi:10.5348/ijcri-2013-01-266-CI-20

$$
* * * * * * * * *
$$

\section{Author Contributions}

Satyaki Ganguly - Substantial contributions to conception and design, Acquisition of data, Drafting the article, Revising it critically for important intellectual content, Final approval of the version to be published Kranti C Jaykar - Substantial contributions to analysis and interpretation of data, Drafting the article, Final approval of the version to be published

Sambeet Kumar Mallik - Substantial contributions to acquisition of data, Drafting the article, Final approval of the version to be published

\section{Guarantor}

The corresponding author is the guarantor of submission.

\section{Conflict of Interest}

Authors declare no conflict of interest.

\section{Copyright}

(C) Satyaki Ganguly et al. 2013; This article is distributed under the terms of Creative Commons Attribution 3.0 License which permits unrestricted use, distribution and reproduction in any means provided the original authors and original publisher are properly credited. (Please see www.ijcasereportsandimages.com/ copyright-policy.php for more information.)

\section{REFERENCES}

1. Sneddon IB, Roberts BM. An incomplete form of acanthosis nigricans. $\mathrm{J} \quad \mathrm{Br}$ Soc Gastroent 1962;3:269-72.

2. Schwartz RA. Sign of Lesser-Trélat. J Am Acad Dermatol 1996 Jul;35(1):88-95.

3. Fanti PA, Metri M, Patrizi A. The sign of Leser-Trélat associated with malignant melanoma. Cutis 1989 Jul;44(1):39-41.

4. Halevy S, Sandbank M. Transformation of lymphocytoma cutis into a malignant lymphoma in association with the sign of Leser-Trélat. Acta Derm Venereol 1987;67(2):172-5.

5. Shamsadini S, Wadji MB, Shamsadini A. Surrounding ipsilateral eruptive seborrheic keratosis as a warning sign of intraductal breast carcinoma and Paget's disease (Leser Trelat sign). Dermatol Online J 2006 Oct 31;12(6):27.

6. Ikari Y, Ohkura M, Morita M, Seki K, Kubota Y, Mizoguchi M. Leser-Trélat sign associated with Sézary syndrome. J Dermatol 1995 Jan;22(1):62-7. 
7. Flugman SL, McClain SA, Clark RA. Transient eruptive seborrheic keratoses associated with erythrodermic psoriasis and erythrodermic drug eruption: report of two cases. J Am Accad Dermatol 2001 Dec;45(6 Suppl):S212-4.

Access full text article on other devices

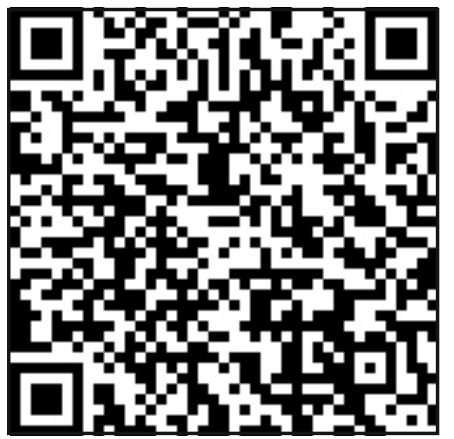

Access PDF of article on other devices

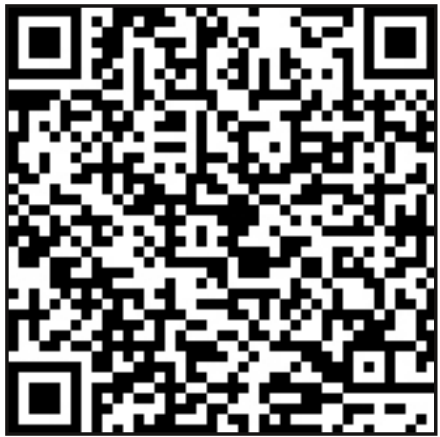

